\title{
Sodium valproate stimulates potassium and chloride urinary excretion in rats: gender differences Eitautė Jakutiene ${ }^{1}$, Jurgita Grikiniene1, Arunas Vaitkevicius², Marina Tschaika ${ }^{3}$, Janina Didziapetriene ${ }^{4}$ and Donatas Stakisaitis*4
}

\author{
Address: ${ }^{1}$ Vilnius University Children's Hospital, Vilnius, Lithuania, ${ }^{2}$ Neurology and Neurosurgery Clinic, Vilnius University, Vilnius, Lithuania, \\ ${ }^{3}$ PharmaEast GmbH, Berlin, Germany and ${ }^{4}$ Institute of Oncology, Vilnius University, Vilnius, Lithuania \\ Email: Eitautė Jakutiene - jeitau@gmail.com; Jurgita Grikiniene - jurgita.grikiniene@mf.vu.lt; Arunas Vaitkevicius - arv@takas.lt; \\ Marina Tschaika - m.tschaika@pharmaeast.de; Janina Didziapetriene - janina.didziapetriene@loc.lt; \\ Donatas Stakisaitis* - donatasstakisaitis@vvkt.lt \\ * Corresponding author
}

Published: 6 August 2007

BMC Pharmacology 2007, 7:9 doi:10.1/86/I47|-2210-7-9

This article is available from: http://www.biomedcentral.com/I47/-22/0/7/9

(c) 2007 Jakutiene et al; licensee BioMed Central Ltd.

This is an Open Access article distributed under the terms of the Creative Commons Attribution License (http://creativecommons.org/licenses/by/2.0), which permits unrestricted use, distribution, and reproduction in any medium, provided the original work is properly cited.
Received: 17 November 2006

Accepted: 6 August 2007

\begin{abstract}
Background: The diuretic effect of valproates and its relation to urinary potassium $\left(\mathrm{K}^{+}\right)$and chloride $(\mathrm{Cl})$ excretion have not yet been investigated, so the aim of this study was to evaluate the influence of a single dose of sodium valproate ( $\mathrm{NaVPA}$ ) on 24-h urinary $\mathrm{K}^{+}$and $\mathrm{Cl}^{-}$excretion in young adult Wistar rats of both genders. For measurement of $\mathrm{K}^{+}$in urine, the same animals and samples as in our earlier publication were used (Pharmacology 2005 Nov, 75:III-II5). The authors propose a new approach to the pathophysiological mechanisms of NaVPA effect on $\mathrm{K}^{+}$and $\mathrm{Cl}$ metabolism.

Twenty six Wistar rats were examined after a single intragastric administration of $300 \mathrm{mg} / \mathrm{kg}$ NaVPA (I 3 NaVPA-male and I 3 NaVPA-female), 28 control intact Wistar rats (I4 males and I4 females) were studied as a control group. The 24-h urinary $\mathrm{K}^{+}, \mathrm{Cl}^{-}$, creatinine and $\mathrm{pH}$ levels were measured.

Results: Total 24-h diuresis and 24-h diuresis per $100 \mathrm{~g}$ of body weight were found to be significantly higher in NaVPA-rats of both genders than in rats of the control group $(p<0.05)$. The data showed NaVPA to enhance $24-\mathrm{h} \mathrm{K}^{+}$excretion in NaVPA-males and NaVPA-females with significant gender-related differences: $24-\mathrm{h} \mathrm{K}^{+}$excretion in NaVPA-male rats was significantly higher than in control males $(p=0.003)$ and NaVPA-female rats $(p<0.00 \mathrm{I})$. Regarding the 24-h $\mathrm{K}^{+}$ excretion, NaVPA-female rats did not show a statistically significant difference versus females of the control group ( $p>0.05$ ). 24-h urinary $\mathrm{K}^{+}$excretion per $100 \mathrm{~g}$ of body weight in NaVPA-male rats was significantly higher than in control males $(p=0.025)$. NaVPA enhanced $\mathrm{Cl}^{-}$urinary excretion: 24-h Cl- urinary excretion, 24-h urinary $\mathrm{Cl}$ - excretion per $100 \mathrm{~g}$ of body weight and the $\mathrm{Cl} /$ creatinine ratio were significantly higher in NaVPA-male and NaVPA-female rats than in gendermatched controls ( $P<0.05$ ). 24-h chloriduretic response to NaVPA in male rats was significantly higher than in female rats $(p<0.05)$.
\end{abstract}

Conclusion: NaVPA causes kaliuretic and chloriduretic effects with gender-related differences in rats. Further investigations are necessary to elucidate the mechanism of such pharmacological effects of NaVPA. 


\section{Background}

Currently there are experimental data that valproate (branched-chain fatty acid, valproic acid) increases the turnover of $\gamma$-aminobutyric acid (GABA) and thereby potentiates GABAergic functions [1]. The specificity of valproate for GABA suggests that this interaction may be an important mechanism through which sodium valproate (NaVPA) exerts its pharmacological effects [2]. Recently NaVPA has shown to enhance the urinary excretion of sodium $\left(\mathrm{Na}^{+}\right)$and chloride $(\mathrm{Cl})$ ions in both genders, but the 24-h chloriduretic response in male rats to NaVPA was significantly higher than in female rats [3]. The effect of NaVPA on potassium ion $\left(\mathrm{K}^{+}\right)$excretion was not yet studied.

The aim of the present study was to evaluate the effect of $\mathrm{NaVPA}$ on urininary $\mathrm{K}^{+}$and $\mathrm{Cl}^{-}$excretion in Wistar rats of both genders and to discuss the NaVPA effects on $\mathrm{K}^{+}$and $\mathrm{Cl}^{-}$metabolism that could be related to NaVPA pharmacological properties.

The GABA type A receptor (GABA(A)) is an ionotropic receptor. Its subunits form a functional $\mathrm{Cl}^{-}$channel $[4,5]$. The GABA(A) receptor subunits are expressed in Wistar rat kidney proximal convoluted and straight tubules [6]. The GABA(A) receptor is rapidly activated by valproate in the brain [7]. $\mathrm{Cl}^{-}$channels play a critical role in the functioning of the nervous system by asserting control over voltage potentials across the plasma membrane [8]. There are gender-related differences in $\mathrm{Cl}^{-}$transport across the cell membrane, intracellular $\mathrm{Cl}^{-}$level and the sensitivity of $\mathrm{Cl}^{-}$ transport to vasopressin in smooth muscle cells of rats [9]. Intracellular $\mathrm{Cl}^{-}$level and $\mathrm{Cl}^{-}$transport differences could be important in the regulation of cellular processes and could help to explain certain functional differences of cells $[9,10]$. $\mathrm{Cl}$ - is an important factor of intracellular $\mathrm{pH}$ [11], which is involved in the complex of cell function regulation.

Investigations show that $\mathrm{K}^{+}-\mathrm{Cl}^{-}$cotransport takes part in the regulation of signaling pathways involved in several tissue and cell types from different species [12]. In modeling $\mathrm{Cl}^{-}$transport in the rat proximal tubule, Weinstein has found that $\mathrm{Cl}^{-}$ions efflux from the cell predominantly via the $\mathrm{K}^{+}-\mathrm{Cl}^{-}$cotransport mechanism [13]. The intracellular $\mathrm{Cl}^{-}$level is dependent upon the $\mathrm{K}^{+}-\mathrm{Cl}^{-} \mathrm{co}-$ transporter (KCC) that determines whether neurons respond to GABA by depolarization or hyperpolarization. However, the role of KCC-dependent chloride homeostasis in the regulation of spontaneous activity of neuronal circuits via GABA(A) receptor is still unknown. Findings suggest that KCCdependent chloride homeostasis is mainly involved in GABA(A) receptor-mediated synaptic inhibition [14]. There are no investigational data on the interaction between KCC and GABA receptors, $\mathrm{K}^{+}$homeostasis or $\mathrm{NaVPA}$ effects on $\mathrm{K}^{+}$and $\mathrm{Cl}^{-}$transport in the kidney.

The study provides data to show that NaVPA in rats, along with the known diuretic and chloriduretic effects, causes also a kaliuretic effect that has not yet been investigated. For measurement of $\mathrm{K}^{+}$in urine, the same animals and samples as in our earlier publication were used (Pharmacology 2005 Nov, 75:111-115).

\section{Methods}

Twenty-six Wistar rats (13 NaVPA-males and 13 NaVPAfemales) were examined after a single intragastric dose of $300 \mathrm{mg} / \mathrm{kg}$ sodium valproate (Convulex, $300 \mathrm{mg} / \mathrm{ml}$, drops (water solution, $\mathrm{pH}$ 9.0), Gerot Pharmazeutika Wien, Austria). In addition, 28 Wistar intact rats (14 males and 14 females) were examined as a control group. NaVPA dosage was chosen in accordance with data of preclinical pharmacodynamic studies of NaVPA [15]. The study was approved by the Lithuanian Committee for Animals Care and Use (No. 0019; 2005). The mean age of control rats was $91 \pm 9$ days for males and $90 \pm 8$ days for females, and the mean age of NaVPA-rats was $97 \pm 10$ days for males and $95 \pm 9$ days for females. The mean weight of male rats was $283 \pm 30 \mathrm{~g}$ in control group and $298 \pm 23 \mathrm{~g}$ in NaVPA-rats. The mean weight of female rats was $236 \pm$ $18 \mathrm{~g}$ in control and $240 \pm 16 \mathrm{~g}$ in NaVPA-rats. The weight was significantly higher in male than in female rats in both groups $(\mathrm{p}<0.05)$.

The animals were housed in standard colony cages with free access to food (chow pellets) and tap water. The room temperature was $21 \pm 1^{\circ} \mathrm{C}$. The rats were on a natural light-dark cycle. All experiments were performed according to the institutional guidelines for animal care in order to avoid any unnecessary distress to the animals and to reduce the number of animals used. The animals were housed in described conditions and acclimated for at least 5 days before experiments. 24-h urine was collected keeping a rat alone in a special cage (diuresis cage for rats 3700D000/3701D000, Tecniplast, Italy) for $24 \mathrm{~h}$ (from 9:00 a.m. till 9:00 a.m. of the next day) with free access to tap water, without food, in the same temperature and light conditions. 24-h urine was collected after a single dose administration.

24-h urinary $\mathrm{K}^{+}, \mathrm{Cl}^{-}$levels were analyzed with an EML-105 electrolyte analyzer (Radiometer, Denmark). Urinary $\mathrm{pH}$ levels were measured with a $\mathrm{pH} / \mathrm{mV} /$ ion meter (ION Meter $\mathrm{pH}$ 340/ION, Germany).

We calculated the 24-h excretion of $\mathrm{K}^{+}, \mathrm{Cl}^{-}$, creatinine, $\mathrm{K}^{+}$/ creatinine, $\mathrm{Cl}^{-} /$creatinine ratio, as well as 24 -h diuresis and 24-h urinary $\mathrm{K}^{+}, \mathrm{Cl}^{-}$excretion per $100 \mathrm{~g}$ of body weight. Data were expressed as mean \pm SD values from $n$ 
animals. Comparisons between the groups were carried out using Student' s t test. A value of $\mathrm{p}<0.05$ was considered significant. Correlations between two variables were investigated by the method of linear correlation analysis. The Pearson correlation coefficient $r$, which represents the linear relationship between two variables, was applied; a value of $\mathrm{p}<0.05$ was considered significant. STATISTICA for Windows software (StatSoft, USA, 1995) was used to perform the analysis of our data.

\section{Results}

\section{Diuresis in control and NaVPA-rats}

24-h diuresis in control rats showed no statistically significant gender-related differences ( $p>0.05)$. 24-h diuresis per $100 \mathrm{~g}$ of body weight in control female rats $(3.90 \pm$ $1.10 \mathrm{ml} / 100 \mathrm{~g})$ was significantly higher $(\mathrm{p}<0.02)$ than in control male rats $(2.89 \pm 0.91 \mathrm{ml} / 100 \mathrm{~g})$. After a single intragastric administration of $300 \mathrm{mg} / \mathrm{kg} \mathrm{NaVPA}$, 24-h diuresis was significantly $(\mathrm{p}<0.05)$ higher in both genders as compared to control groups, without statistically significant gender-related differences (Table 1). 24-h diuresis per $100 \mathrm{~g}$ of body weight in NaVPA-females $(5.04 \pm$ $1.66 \mathrm{ml} / 100 \mathrm{~g})$ and NaVPA-males $(5.38 \pm 2.41 \mathrm{ml} / 100 \mathrm{~g})$ was significantly higher $(\mathrm{p}<0.05)$ than in control female and male rat groups $(3.90 \pm 1.10 \mathrm{ml} / 100 \mathrm{~g}, 2.89 \pm 0.91$ $\mathrm{ml} / 100 \mathrm{~g}$, respectively), with no statistically significant gender-related differences.

No statistically significant correlation between 24 -h diuresis and 24-h urinary $\mathrm{K}^{+}$excretion or between 24 -h diuresis and 24-h urinary $\mathrm{Cl}^{-}$excretion was found in male and female control rats $(p>0.05)$. Statistically significant correlations between 24-h diuresis and 24-h $\mathrm{K}^{+}$excretion $(\mathrm{r}=$ $0.64 ; \mathrm{p}<0.05)$ were found in NaVPA-males. There were no statistically significant correlations between diuresis and 24-h urinary $\mathrm{K}^{+}$excretion in NaVPA-females ( $\mathrm{p}>0.05$, Figure 1). In NaVPA-male rats, the negative correlation between $\mathrm{Cl}^{-}$excretion and 24-h diuresis $(\mathrm{r}=-0.56)$ and between $\mathrm{Cl}^{-}$excretion and urine $\mathrm{pH}(\mathrm{r}=-0.73)$ was significant $(\mathrm{r}=-0.73 ; \mathrm{p}<0.05)$, and no such correlations were found for NaVPA-female rats $(\mathrm{r}=0.18$ and $\mathrm{r}=0.02 ; \mathrm{p}>$ 0.05 , Figure 2, 3).

\section{$\mathrm{K}^{+}$excretion in control and NaVPA-rats}

No statistically significant gender-related differences in 24-h urine $\mathrm{K}^{+}$excretion and in the $\mathrm{K}^{+} /$creatinine ratio were determined in control rats $(\mathrm{p}>0.05)$. 24-h urinary $\mathrm{K}^{+}$ excretion per $100 \mathrm{~g}$ of body weight was significantly higher in control females than in control males $(\mathrm{p}=0.04$; Table 1). 24-h $\mathrm{K}+$ excretion in NaVPA-male rats was significantly higher than in control male $(\mathrm{p}=0.003)$ and NaVPA-female rats $(\mathrm{p}<0.001) .24-\mathrm{h} \mathrm{K}^{+}$excretion in NaVPA-female rats did not show statistically significant difference versus female controls ( $p>0.05$ ). 24-h urinary $\mathrm{K}^{+}$excretion per $100 \mathrm{~g}$ of body weight in NaVPA-male rats was significantly higher than in control males $(\mathrm{p}=0.025$; Table 1). No gender-related differences in this index were found in NaVPA-rats. This index in NaVPA-female rats did not show any statistically significant difference as compared with female controls $(\mathrm{p}>0.05)$.

The $\mathrm{K}^{+} / \mathrm{Cl}^{-}$ratio (Table 2) in NaVPA-males and NaVPAfemales was significantly lower as compared to control males ( $\mathrm{p}<0.0005)$ and control females ( $\mathrm{p}<0.0005)$, without any statistically significant gender-related differences.

\section{Cl- excretion in control and NaVPA-rats}

No significant gender differences of 24-h urine, $\mathrm{Cl}^{-}$excretion and $\mathrm{Cl}^{-}$excretion per $100 \mathrm{~g}$ of body weight and $\mathrm{Cl}-1$ creatinine ratio were determined in control rats, either ( $\mathrm{p}$ $>0.05$; Table 2).

Compared to control, 24-h urinary $\mathrm{Cl}^{-}$levels were significantly $(\mathrm{p}<0.05)$ higher in both genders of experimental animals. 24-h urinary $\mathrm{Cl}^{-}$excretion, 24-h urinary $\mathrm{Cl}$ - excretion per $100 \mathrm{~g}$ of body weight and the $\mathrm{Cl} /$ creatinine ratio in both sexes of NaVPA-rats were significantly higher than in gender-matched controls $(\mathrm{p}<0.001)$. Chloride excretion (24-h urinary $\mathrm{Cl}^{-}$excretion, 24-h urinary $\mathrm{Cl}$ - excretion per $100 \mathrm{~g}$ of body weight and the $\mathrm{Cl} /$ creatinine ratio) was

Table I: Diuresis and 24-h urinary $\mathrm{K}^{+}$excretion in male and female control and NaVPA-rat groups (mean \pm SD)

\begin{tabular}{|c|c|c|c|c|c|c|}
\hline Rat groups & $\mathrm{n}$ & 24-h diuresis $(\mathrm{ml})$ & 24-h K+ level (mmol/l) & 24-h K+ excretion (mmol) & $\begin{array}{l}\text { 24-h } \mathrm{K}^{+} \text {excretion per } 100 \mathrm{~g} \\
\text { body weight }(\mathrm{mmol})\end{array}$ & $\mathrm{K}^{+} /$creatinine ratio \\
\hline \multicolumn{7}{|l|}{ Control rats } \\
\hline females & 14 & $9.1 \pm 2.3$ & $116 \pm 27$ & $1.01 \pm 0.17$ & $0.43 \pm 0.06^{*}$ & $13.9 \pm 3.38$ \\
\hline males & 14 & $8.0 \pm 2.1$ & $135 \pm 29$ & $1.04 \pm 0.18$ & $0.37 \pm 0.08 *$ & $12.7 \pm 7.9$ \\
\hline \multicolumn{7}{|l|}{ NaVPA-rats } \\
\hline females & 13 & $12.1 \pm 4.1^{\circ}$ & $84 \pm 28$ & $0.93 \pm 0.14^{*}$ & $0.39 \pm 0.06$ & $11.8 \pm 2.34$ \\
\hline males & 13 & $16.0 \pm 7.2^{\bullet}$ & $93 \pm 30^{\circ}$ & $1.32 \pm 0.26^{\circ} *$ & $0.44 \pm 0.08$ & $12.4 \pm 2.88$ \\
\hline
\end{tabular}

- Statistically significant difference as compared to control group $(p<0.05)$.

$*$ - Statistically significant difference versus the other gender $(p<0.05)$. 


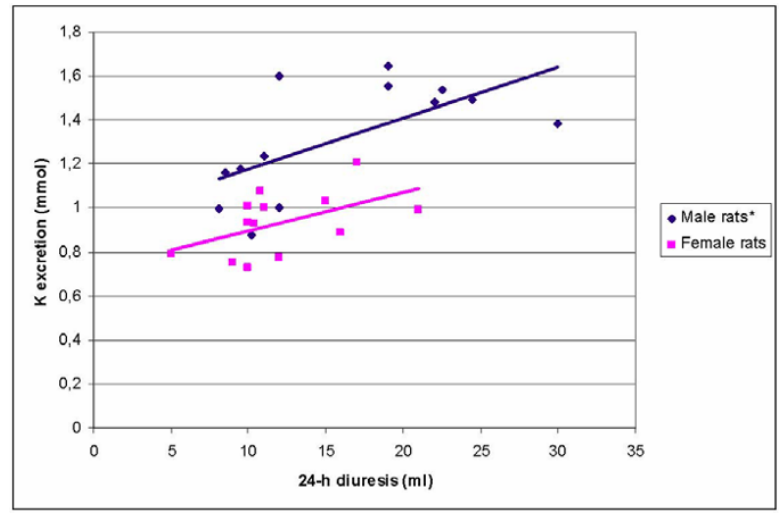

Figure I

Correlation between 24-h diuresis and $\mathrm{K}^{+}$excretion in NaVPA male and female rats. * - Statistically significant correlation.

found significantly higher in NaVPA-male than in NaVPAfemale rats ( $\mathrm{p}<0.05$; Table 2). 24-h creatinine excretion in NaVPA-male rats $(0.110 \pm 0.025 \mathrm{mmol})$ was significantly higher than in NaVPA-female rats $(0.082 \pm 0.017$ mmol; $\mathrm{p}<0.005)$. No gender-related difference in 24-h creatinine excretion between control male and female rats was determined $(\mathrm{p}>0.05)$.

The 24-h urine $\mathrm{pH}$ showed no statistically significant difference between control females $(6.57 \pm 0.2)$ and control males $(6.53 \pm 0.2 ; \mathrm{p}>0.05)$. The 24 -h urine $\mathrm{pH}$ in NaVPAmales $(6.42 \pm 0.3)$ and NaVPA-females $(6.43 \pm 0.3)$ showed no statistically significant differences from controls and between the genders ( $p>0.05)$. In NaVPA-rats, only the correlation between $\mathrm{Cl}^{-}$excretion and 24-h urine

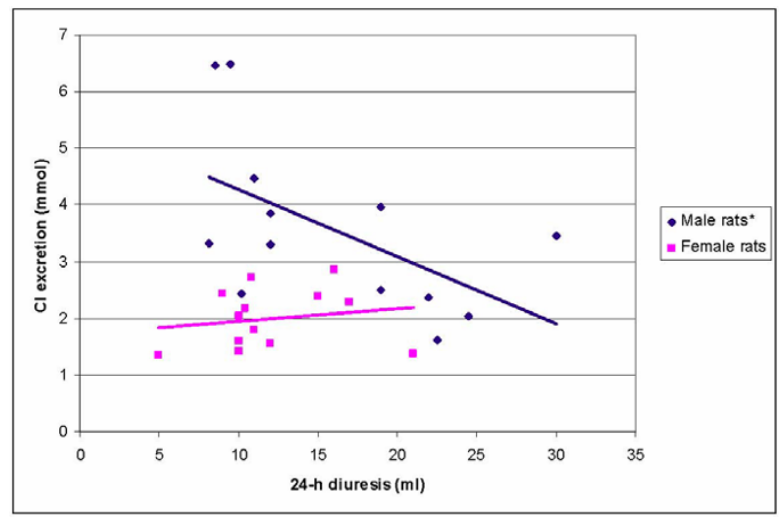

Figure 2

Correlation between 24-h diuresis and $\mathrm{Cl}^{-}$excretion in NaVPA male and female rats. * - Statistically significant correlation.

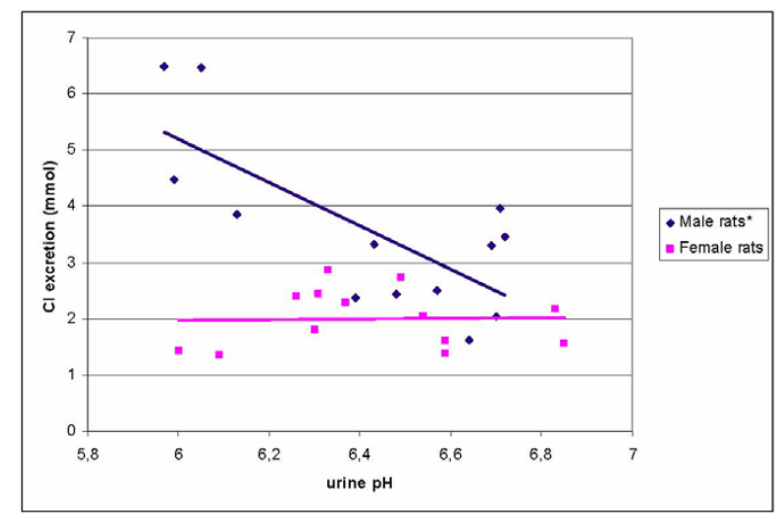

Figure 3

Correlation between urine $\mathrm{pH}$ and $\mathrm{Cl}$ - excretion in NaVPA male and female rats. ${ }^{*}$ - Statistically significant correlation.

$\mathrm{pH}$ was significant in NaVPA-males $(\mathrm{r}=-0.73$; $\mathrm{p}<0.05$, Figure 3). The correlation coefficient of 24-h urinary $\mathrm{Cl}^{-}$ excretion and urine $\mathrm{pH}$ statistically significantly differed $(\mathrm{p}<0.02)$ between control males $(\mathrm{r}=0.03)$ and NaVPAmales ( $\mathrm{r}=-0.73)$, also between NaVPA-females and NaVPA-males $(r=0.02, r=-0.73, p<0.05)$, without any statistically significant differences in control females and males $(\mathrm{p}>0.05)$.

The correlation between 24 -h urinary $\mathrm{K}^{+}$and $\mathrm{Cl}^{-}$excretion and between respective electrolyte and 24-h urine $\mathrm{pH}$ in control male and female rats was not statistically significant ( $p>0.05)$. The correlation coefficient of 24-h urinary $\mathrm{K}^{+}$excretion and 24-h urinary $\mathrm{Cl}^{-}$excretion statistically significantly differed $(\mathrm{p}=0.03$ ) only between control males $(\mathrm{r}=-0.28)$ and control females $(\mathrm{r}=0.49)$.

\section{Discussion}

$\mathrm{Cl}^{-}$and $\mathrm{K}^{+}$fluxes play a crucial role in synaptic inhibition, cell $\mathrm{pH}$ regulation, as well as in cell volume control and tissue susceptibility to seizures $[16,17]$. A recent study showed that NaVPA, alongside the diuretic effect, enhances sodium and $\mathrm{Cl}^{-}$excretion with urine [3]. Acute and subacute administration of valproic acid has been shown to exert a moderate diuretic effect on rats $[9,18,19]$.

The study data showed that intragastric $300 \mathrm{mg} / \mathrm{kg}$ NaVPA significantly increased $24-\mathrm{h} \mathrm{K}^{+}$excretion in the urine of NaVPA-male rats. 24-h $\mathrm{K}^{+}$excretion in NaVPA-male rats was significantly higher than in control males and NaVPA-female rats. 24-h urinary $\mathrm{K}^{+}$excretion per $100 \mathrm{~g}$ of body weight in NaVPA-male rats was significantly higher than in control male rats. 
Table 2: 24-h urinary chloride ( $\left.\mathrm{Cl}^{-}\right)$excretion data and $\mathrm{K}^{+} / \mathrm{Cl}^{-}$ratio in male and female control and NaVPA-rat groups (mean \pm SD)

\begin{tabular}{|c|c|c|c|c|c|c|}
\hline Rat groups & $\mathrm{n}$ & 24-h Cl- level (mmol/l) & 24-h Cl- excretion (mmol/24 h) & $\begin{array}{l}\text { 24-h } \mathrm{Cl}^{-} \text {excretion per } 100 \mathrm{~g} \\
\text { body weight }(\mathrm{mmol} / 100 \mathrm{~g})\end{array}$ & $\mathrm{Cl} /$ creatinine ratio & $\mathrm{K}^{+} / \mathrm{Cl}^{-}$ratio \\
\hline \multicolumn{7}{|l|}{ Control rats } \\
\hline females & 14 & $104 \pm 51$ & $0.886 \pm 0.40$ & $0.371 \pm 0.15$ & $12.6 \pm 6.9$ & $1.30 \pm 0.44$ \\
\hline males & 14 & $168 \pm 128$ & $\mathrm{I} .164 \pm 0.70$ & $0.420 \pm 0.26$ & $14.2 \pm 8.8$ & $1.15 \pm 0.54$ \\
\hline \multicolumn{7}{|l|}{ NaVPA-rats } \\
\hline females & 13 & $180 \pm 60^{\circ}$ & $1.997 \pm 0.52 \cdot *$ & $0.833 \pm 0.22 * *$ & $24.6 \pm 4.7 \cdot *$ & $0.49 \pm 0.12^{\circ}$ \\
\hline males & 13 & $275 \pm 184^{\bullet}$ & $3.396 \pm 1.21 \cdot *$ & $1.208 \pm 0.53^{*} *$ & $34.6 \pm 16.5^{*} *$ & $0.45 \pm 0.22$ \\
\hline
\end{tabular}

- Statistically significant difference, as compared to control group $(p<0.05)$.

$*$ - Statistically significant difference versus the other gender $(p<0.05)$.

The enhanced excretion of $\mathrm{K}^{+}$and $\mathrm{Cl}^{-}$with urine and the related gender differences of NaVPA effect could be important for elucidating the pathophysiological phenomena related to NaVPA pharmacology. GABA functions appear to be triggered by GABA binding to its ionotropic receptors, which are ligand-gated $\mathrm{Cl}^{-}$channels $[4,5]$. The $\mathrm{Cl}^{-}$channel of the GABA(A) receptor is activated by valproic acid in brain cells [7]. GABA was also found to activate $\mathrm{K}^{+}$conductance in the central nervous system [20], it is involved in a wide variety of physiological functions in tissues and organs outside the brain $[12,21]$. Activation of the GABA(A) receptor leads to a stimulation of $\mathrm{Na}^{+}-\mathrm{K}^{+}-2 \mathrm{Cl}^{-}$cotransporter in brain cells, and this results in a loss of intracellular $\mathrm{Cl}^{-}$[22] or in an upregulation of KCC which is important in maintaining the low intracellular $\mathrm{Cl}^{-}$level [23].

Studies demonstrating $\mathrm{K}^{+} \mathrm{Cl}^{-}$cotransport in rabbit proximal tubules have shown a coupled $\mathrm{K}^{+}-\mathrm{Cl}^{-}$movement from the cell to peritubular fluid [24]. In addition, several modes of coupled $\mathrm{K}^{+}$and $\mathrm{Cl}^{-}$movement have been shown in $\mathrm{K}^{+}$excretion by renal tubules: directly coupled $\mathrm{K}^{+} \mathrm{Cl}^{-}$ cotransport, parallel $\mathrm{K}^{+}$and $\mathrm{Cl}^{-}$conductance, parallel $\mathrm{K}^{+} /$ $\mathrm{H}^{+}$and $\mathrm{Cl}^{-} / \mathrm{HCO}^{-}$exchangers and $\mathrm{Na}^{+}-\mathrm{K}^{+}-2 \mathrm{Cl}^{-}$cotransport [25]. In modeling $\mathrm{Cl}^{-}$transport in the rat proximal tubule, Weinstein found that $\mathrm{Cl}^{-}$effluxes from the cell predominantly via $\mathrm{K}^{+}-\mathrm{Cl}^{-}$cotransport [13].

The presence and physiological significance of GABA or GABA(A) receptors in nonneural tissue is less clear [26]. The effect of pharmacological manipulation of GABAergic transmission on KCC activity in the kidney remains to be clarified. GABA immunoreactivity in the rat kidney was predominantly confined to renal tubules, including the ascending parts of the distal tubules, and the loop of Henle, the collecting tubules and ducts, and the connective parts of the convoluted tubules. The high $\mathrm{K}^{+}$concentration evoked an efflux of endogenous GABA from rat kidney slices. GABA released from renal tubular epithelium and transported with urine might be involved in the modulation of $\mathrm{K}^{+}$transport in the urinary tract cells [27]. However, our findings allow to hypothesize that GABA(A) subunits may play a role in basolateral membrane $\mathrm{Cl}^{-}$ transport. These findings support the suggestion of other investigators, that subunits of the ligand-gated $\mathrm{Cl}^{-}$channel superfamily may be involved in renal $\mathrm{Cl}^{-}$excretion [6].

NaVPA exerts a gender-related effect on urinary $\mathrm{Cl}^{-}$excretion: 24-h urinary $\mathrm{Cl}^{-}$excretion was significantly higher in rats of both sexes, but $\mathrm{Cl}^{-}$excretion was significantly higher in male than in female rats. In NaVPA-male rats, the negative correlation between $\mathrm{Cl}^{-}$excretion and 24-diuresis and between $\mathrm{Cl}^{-}$excretion and urine $\mathrm{pH}$ was significant, but such correlations were not characteristic of control male or NaVPA-female rats. The $\mathrm{K}^{+} / \mathrm{Cl}^{-}$ratio in NaVPA-males and NaVPA-females was significantly lower as compared to control males and control females, without gender-related differences. There are no data that could contribute to elucidating the mechanisms of NaVPA-induced enhanced urinary $\mathrm{Cl}^{-}$excretion. It is known that the alkaline extracellular $\mathrm{pH}$ increases the $\operatorname{GABA}(\mathrm{A})$ channel opening frequency and decreases the duration of the long-closed state in rat hypothalamus [28]. There are no data that NaVPA influences tubular intracellular and extracellular pH. Gender-related differences in intracellular $\mathrm{Cl}^{-}$concentration and $\mathrm{Cl}^{-}$transport in smooth muscle cells of male and female rats have been reported [9]. Sexual dimorphism in the expression of KCC, GABA receptors and in GABA release in the nervous system of rats is a known fact [29-35].

Tissue distribution studies with radiolabeled NaVPA in rodents have shown that NaVPA distributed mainly in the extracellular space; high levels of radiolabeled NaVPA were found in the liver and kidney [36]. We failed to find data on gender-related differences of NaVPA pharmacokinetics, pharmacodynamics, or gender differences of NaVPA metabolism in rats. The NaVPA-induced $\mathrm{K}^{+}$and $\mathrm{Cl}^{-}$excretion enhancement may be related to the upregulated renal hemodynamics, as the NaVPA doses applied are known to reduce arterial blood pressure in rats: NaVPA provoked a prolonged cardiovascular depression which was very similar to that observed with high i.v. doses of GABA $[18,37]$. The mechanism of the cardio depressive 
effect of NaVPA is not clear; it seems not to involve interference with peripheral vascular noradrenergic activity or arterial baroreflex control [38]. Furthermore, $\mathrm{Cl}^{-}$is an important factor of renal vascular tone or renal hemodynamics regulation. Renal arterial infusion of $\mathrm{Cl}^{-}$acts as a direct vasoconstrictor [39]; retrograde injection of $\mathrm{Cl}^{-}-$ containing solution into the distal tubule elicits a decrease in a single nephron glomerular filtration rate, whereas injection of sodium ion containing solution without $\mathrm{Cl}^{-}$ does not [40]. In oncotically perfused rat kidneys, in the presence of either high or low $\mathrm{Cl}^{-}$with sodium kept constant, low $\mathrm{Cl}^{-}$resulted in a higher glomerular filtration rate than with high chloride [41]. It is not likely that the NaVPA-induced gender-related $\mathrm{K}^{+}$and $\mathrm{Cl}^{-}$excretion is linked to $\mathrm{Na}^{+}-\mathrm{K}^{+}-2 \mathrm{Cl}^{-}$cotransporter inhibition, because the $\mathrm{Na}^{+}-\mathrm{K}^{+}-2 \mathrm{Cl}^{-}$cotransporter inhibitor furosemide exerts an opposite gender-related chloriduretic effect in rats [42].

\section{Conclusion}

NaVPA, alongside the diuretic effect, enhances $\mathrm{K}^{+}$and $\mathrm{Cl}^{-}$ excretion with urine in rats of both genders. The mechanism of this different gender-dependent effect is not yet clear. The experimental observations reported above may have potentially important pharmacological implications. Elucidation of NaVPA-induced mechanisms of enhanced $\mathrm{K}^{+}$and $\mathrm{Cl}^{-}$excretion could be of value while explaining the pharmacological basis of NaVPA action. Thus, further studies of the mechanisms of NaVPA effects on $\mathrm{K}^{+}$and $\mathrm{Cl}^{-}$transport in cells could be important.

\section{Abbreviations \\ $\mathrm{NaVPA}=$ sodium valproate \\ $\mathrm{Cl}^{-}=$chloride \\ $\mathrm{K}^{+}=$potassium \\ $\mathrm{KCC}=\mathrm{K}-\mathrm{Cl}$ co-transporter}

\section{Authors' contributions}

All coauthors took part in conceiving, designing and coordinating the study; Jakutiene $\mathrm{E}$ and Grikiniene J performed the experiments; Grikiniene J and Vaitkevicius A analysed the data; Jakutiene E, Stakisaitis D wrote the paper. All authors were involved in drafting, revising and approving the manuscript.

\section{References}

I. Loscher W: Basic pharmacology of valproate: a review after 35 years of clinical use for the treatment of epilepsy. CNS Drugs 2002, 1 6:669-694.

2. Balding F Jr, Geller HM: Sodium valproate enhancement of gamma-aminobutyric acid (GABA) inhibition: electrophysiological evidence for anticonvulsant activity. J Pharmacol Exp Ther 1981, 2 I 7:445-450.

3. Grikiniene J, Stakisaitis D, Tschaika M: Influence of sodium valproate on sodium and chloride urinary excretion in rats, gender differences. Pharmacology 2005, 75: I II-II5.
4. Bureu M, Laschet J, Minier F, Chauvel P: Intervention of GABAergic neurotransmission in partial epilepsies. Rev Neurol 1997, I 53:S46-S54.

5. Fritschy JM, Mohler H: GABAA-receptor heterogeneity in the adult rat brain: differential regional and cellular distribution of seven major subunits. Comp Neurol 1995, 359: I54-I94.

6. Sarang SS, Plotkin MD, Gullans SR, Cummings BS, Grant DF, Schnellmann RG: Identification of the gamma-aminobutyric acid receptor beta (2) and beta (3) subunits in rat, rabbit, and human kidneys. J Am Soc Nephrol 200 I, I 2: I I07-I I I 3.

7. Armijo JA, de las Cuevas I: Adin J. Ion channels and epilepsy. Rev Neurol 2000, 30(Suppl I):S25-S4I.

8. Yogeeswari P, Ragavendran JV, Thirumurugan R, Saxena A, Sriram D: lon channels as important targets for antiepileptic drug design. Curr Drug Targets 2004, 5:589-602.

9. Stakisaitis D, Daugirdas JT: Sexual dimorphism in chloride transport in cultured rat aortic VSMCs. Am J Physiol 1996, A9:22.

10. Stakisaitis D, LaPointe MS, Battle D: Intracellular chloride of lymphocytes and hypertension. J Investig Med 1998, 45:324A.

II. Stakisaitis D, LaPointe MS, Battle D: Mechanisms of chloride transport in thymic lymphocytes. Am J Physiol Renal Physiol 200 I, 280:F3 |4-324.

12. Adragna NC, Fulvio MD, Lauf PK: Regulation of K-Cl cotransport: from function to genes. J Membr Biol 2004, 20 I: I09-I 37.

13. Weinstein AM: Chloride transport in a mathematical model of the rat proximal tubule. Am J Physiol 1992, 263:F784-F798.

14. Xu TL, Wang W: Chloride homeostasis differentially affects GABA(A) receptor and glycine receptor-mediated effects on spontaneous circuit activity in hippocampal cell culture. Neurosci Lett 2006, 406: I I-I6.

15. Loscher W: Valproate: A reappraisal of its pharmacodynamic properties and mechanisms of action. Prog Neurobiol 1999, 58:35-40.

16. Bihi RI, Jefferys JG, Vreugdenhil M: The role of extracellular potassium in the epileptogenic transformation of recurrent GABAergic inhibition. Epilepsia 2005, 46(Suppl 5):64-7I.

17. Muller $M$ : Effects of chloride transport inhibition and chloride substitution on neuron function and on hypoxic spreadingdepression-like depoliarization in rat hippocampal slices. Neurocience 2000, 97:33-45.

18. Shuto K, Nishigaki T: The pharmacological studies on sodium dipropylacetate anticonvulsant activities and general pharmacological actions. Pharmacometrics 1970, 4:937-949.

19. Carraz G, Beriel H, Luu-Duc H, Lebreton S: Approches dans la pharmacodynamie biochimique de la structure $\mathbf{N}$-dipropylacetique. Therapie 1965, 20:419-426.

20. Nicoll RA: My close encounter with GABA(B) receptors. Biochem Pharmacol 2004, 68:1667-1674.

21. Watanabe M, Maemura K, Kanbara K, Tamayama T, Hayasaki $H$ : GABA and GABA receptors in the central nervous system and other organs. Int Rev Cytol 2002, 21 3:1-47.

22. Schomberg SL, Bauer J, Kintner DB, Su G, Flemmer A, Forbush B, Sun $\mathrm{D}$ : Cross talk between the GABA(A) receptor and the $\mathrm{Na}-\mathrm{K}$ Cl cotransporter is mediated by intracellular $\mathbf{C l}$. J Neurophysiol 2003, 89:159-167.

23. Hubner CA, Stein V, Hermans-Borgmeyer I, Meyer T, Ballanyi K, lentsch TI: Disruption of $\mathrm{KCC2}$ reveals as essential role of $\mathrm{K}-\mathrm{Cl}$ cotransport already in early synaptic inhibition. Neuron 2001, 30:515-524.

24. Sasaki S, Ishibashi K, Yoshiyami N, Shiigai I: KCl cotransport across the basolateral membrane of rabbit renal proximal tubules. J Clin Invest 1988, 81:194-197.

25. Ishibachi K, Rector FC, Berry CA: Chloride transport across the basolateral membrane of rabbit proximal convoluted tubules. Am J Physiol 1990, 258:FI569-FI578.

26. Sarang SS, Plotkin MD, Gullans SR, Cummings BS, Grant DF, Schnellmann RG: Identification of the gamma-aminobutyric acid receptor beta(2) and beta(3) subunits in rat, rabbit, and human kidneys. J Am Soc Nephrol 200 I, I 2: I I07-I I I3.

27. Erdo SL, Dobo E, Parducz A, Wolff JR: Releasable GABA in tubular epithelium of rat kidney. Experientia I99I, 47:227-229.

28. Huang RQ, Dillon GH: Effect of extracellular pH on GABA-activated current in rat recombinant receptors and thin hypothalamic slices. J Neurophysiol 1999, 82: I 233-1243.

29. Galanopoulou AS: GABA receptors as broadcasters of sexually differentiating signals in the brain. Epilepsia 2005:107-I I2. 
30. Galanopoulou AS: Sex and cell-type-specific patterns of GABA(A) receptor and estradiol-mediated signaling in the immature rat substantia nigra. Eur J Neurosci 2006, 23:2423-2430.

31. Hu M, Watson CJ, Kennedy RT, Becker JB: Estradiol attenuates the $\mathrm{K}+$-induced increase in extracellular GABA in rat striatum. Synapse 2006, 59:I22-I24.

32. Galanopoulou AS, Moshe SL: Role of sex hormones in the sexually dimorphic expression of KCC2 in rat substantia nigra. Exp Neurol 2003, 184:1003-1009.

33. Ravizza T, Friedman LK, Moshe SL, Veliskova J: Sex differences in GABA(A)ergic system in rat substantia nigra pars reticulata. Int J Dev Neurosci 2003, 2 I:245-254.

34. McCarthy MM, Auger AP, Perrot-Sinal TS: Getting excited about GABA and sex differences in the brain. Trends Neurosci 2002, 25:307-3I2.

35. Pericic D, Manev $H$, Lakic N: Sex differences in the response of rats to drugs affecting GABAergic transmission. Life Sci 1985, 36:54l-547.

36. Schobben F, Van der Klein E: Pharmacokinetics of distribution and elimination of sodium di n-propylacetate in mouse and dogs. Pharmaceut Week 1974, 109:33-4I.

37. Loscher W: Cardiovascular effects of GABA, GABA aminotransferase inhibitors and valproic acid following systemic administration in rats, cats, and dogs. Arch Int Pharmacodyn Ther 1982, 257:32-58.

38. Rotiroli D, Palella B, Losi E, Nistico G, Caputi AP: Evidence that a GABAergic mechanism influences the development of DOCA-salt hypertension in the rat. Eur J Pharmacol 1982, 83: I53-I54.

39. Wilcox CS: Regulation of renal blood flow by plasma chloride. J Clin Invest 1983, 71:726-735.

40. Schnermann JD, Ploth DW, Hermle M: Activation of tubuloglomerular feedback by chloride transport. Pflugers Arch 1976, 362:229-240.

4I. Yin K, McGiff JC, Bell-Quilley CP: Role of chloride in the variable response of the kidney to cyclooxygenase inhibition. $\mathrm{Am} J$ Physiol 1995, 268(4 Pt 2):F56I-F568.

42. Brandoni A, Villar SR, Torres AM: Gender-related differences in the pharmacodynamics of furosemide in rats. Pharmacology 2004, 70:107-II2.

Publish with Biomed Central and every scientist can read your work free of charge

"BioMed Central will be the most significant development for disseminating the results of biomedical research in our lifetime."

Sir Paul Nurse, Cancer Research UK

Your research papers will be:

- available free of charge to the entire biomedical community

- peer reviewed and published immediately upon acceptance

- cited in PubMed and archived on PubMed Central

- yours - you keep the copyright

Submit your manuscript here:

http://www.biomedcentral.com/info/publishing_adv.asp
BioMedcentral 